UDC 614.71(470.313)

\title{
HYGIENIC ASSESSMENT OF AMBIENT AIR QUALITY AND HEALTH RISKS TO POPULATION OF KRASNOYARSK REGION
}

\author{
D.V. Goryaev, I.V. Tikhonova
}

Administration of the Federal Supervision Service for Consumer's Rights Protection and Human Welfare in the Krasnoyarsk Region, 21 Karatanova St., Krasnoyarsk, 660049, Russian Federation

This study fulfills the hygienic assessment of ambient air quality in the populated areas of the Krasnoyarsk Region. It is shown that the total number of emission sources in the region is more than 23600 units, what is higher than in previous years. Around $90.7 \%$ out of them correspond to the set standards of permissible emissions. Air monitoring was carried by the establishments of Roshydromet, Rospotrebnadzor and by other organizations at 94 observation posts in eight urban districts and 2 municipal districts of the region. The status of the ambient air in a sequence of the populated areas of Krasnoyarsk region, namely in the cities Achinsk, Kansk, Krasnoyarsk, Lesosibirsk, Minusinsk, Norilsk, is characterized by the presence of certain pollutants, the level of which exceeds the hygienic standards. Prioritized pollutants are benzo(a)pyrene, suspended solids, nitrogen, and sulfur dioxide, formaldehyde and others. In the settlements the economic entities violate the legal requirements in the field of sanitary and epidemiological welfare of the population. The probability of the population's health deterioration grows along with the growth of risk factors. The risks of respiratory diseases, immune system, blood and blood-forming organs and the additional mortality are assessed as unacceptable. Ensuring air quality of the urban residential areas and municipal districts of the Krasnoyarsk Territory requires the introducing the complex measures to improve it. The established levels of human health risk associated with exposure to polluted air are an additional criterion for selection of the priority objects when planning the implementation of risk-based model for supervisory activities in the field of sanitary and epidemiological welfare of the population.

Key words: hygienic assessment, ambient air quality, populated areas, population's health, health risks to population, territory of risk, subject (object) of economic management, risk-oriented supervision, planning.

In spite of some positive trends characterizing environment our citizens live in we can still detect a set of problems which are to be solved if we want to protect our population health [3]. These problems are related to air, drinking water and soil pollution in settlements. The pollution causes demographic losses in the form of population morbidity and mortality, including children [1,9,10,13-16]. Health loss among working population leads to GDP deficiency and occurrence of economic damages to the state [5]. All these problems make it necessary to work out and implement activities aimed at population health protection. At the same time, environment quality and population health management should be based upon comparative profound hygienic assessment of pollution levels dynamics with the use of hygienic safety criteria, as well as up-to-date guidelines and approaches to health risk assessment. It will help to solve practical tasks in the sphere of environment improvement and population health preservation $[2,4,6,11,12]$.

Nowadays as surveillance organizations in the sphere of sanitary and epidemiologic welfare of population become more efficient our experts have worked out a risk-oriented model based on various principles and using a risk analysis methodology as a reliable and effective tool. Still, this risk-oriented model of Rospotrebnadzor activities requires substantially greater volumes of data including data on legal entities and private entrepreneurs who are subject to surveillance from the point of view of assessing an economic entity profile and number of people being exposed to dangerous factors caused by its activity [8].

Health risk assessment and choice of priorities to organize monitoring and control are among the most important tasks in any region, including Krasnoyarsk region with its population of more than 3 million and multi-factor complex effects influencing environment and being the result of industries, transport and power engineering activities.

Research goal: to assess air quality in Krasnoyarsk region settlements and its influence on population health.

\section{Data and methods}

Hygienic assessment of air quality was accomplished on the basis of Federal Service for Statistics strategic data and the results of 
instrumental observations carried out by Rospotrebnadzor Krasnoyarsk regional office. Risk assessment was accomplished according to $\mathrm{P}$ 2.1.10.1920-04 "Guidelines on assessment of population health risk under exposure to chemicals which pollute environment" with pollution levels taken into account [7].

To analyze dynamics of first detected morbidity among Krasnoyarsk region population we used statistic observation forms called "Information on number of diseases registered in patients living in the area of a medical organization service" and given by Krasnoyarsk Regional Public Health Ministry containing data for 20102014 period. We used MS Excel program to analyze and statistically assess the given data.

\section{Results and discussion}

A number of objects emitting pollutants into air in Krasnoyarsk region settlements was growing annually in 2011-2014 according to Federal Service for Statistics regional office. Thus, in 2014 there were 1029 registered enterprises and organizations and it was $39.2 \%$ higher than in 2011. $90.7 \ldots 99.1 \%$ of them $(726 \ldots 954$ economic entities) had fixed maximum permissible emissions and $0.9 \quad \ldots 2.0 \%\left(\begin{array}{llllll}8 & \ldots & 16 & \text { economic }\end{array}\right.$ entities) had temporarily agreed emissions. At the same time, in 2014 total number of emission sources in the region amounted to 23687 and it was $21.9 \%$ higher than in 2011 (19434); $83.2 \ldots 88.6 \%$ of emission sources (16914 ... 20313) had fixed maximum permissible emissions and $10.7 \ldots$ 13.0\% (2437 ... 2558) had temporarily agreed emissions.

Gross volume of pollutants emissions into settlements atmosphere in Krasnoyarsk region was 2355.784 thousand tons in 2014 which was $6.1 \ldots$ $6.4 \%$ lower than stationary sources emissions both in 2013 (2507.578 thousand tons) and in 2011 (2516.81 thousand tons). The greatest share of emissions $(91.6 \ldots 92.8 \%)$ was detected in 6 areas of Krasnoyarsk region: Norilsk (75.5 ... 78.2\%), Krasnoyarsk (5.5 ... 5.8\%), Turukhansk district $(4.0 \ldots 5.7 \%)$, Nazarov (1.7 .. 2.2\%), Achinsk $(1.68 \ldots 1.76 \%)$ and Sharyipov district (0.99$1.2 \%)$.

In 2011-2014 technogenic burden for the population in the terms of chemical pollutants emitted by industrial enterprises per 1 person living in Krasnoyarsk region was 824.0 ... 909.9 kilos a year and it was 7.3\% lower in 2014 than in 2011. Over 2011-2014 only 7 territories out of 55 in Krasnoyarsk region had much greater technogenic burden than average regional level of pollution per 1 person. Those territories were Nazarovo, Norilsk, Bolsheuluiskiy, Motyiginskiy, Severo-Eniseyskiy, Turukhansliy and Sharyipovskiy districts. The minimum exceeding was registered at 1.1 times and maximum exceeding was 12.6 times; the pollution level was 10393.9 .. 11099.7 kilos/person in Norilsk, 833.3 .. 1182.9 kilos/person in Nazarovo, 1616.0 ... $2488.5 \mathrm{kilos} /$ person in Bolsheuluiskiy district, $291.2 \ldots 1228.3 \mathrm{kilos} /$ person in Motyiginskiy district, 69.7 ... 1357.2 kilos/person in SeveroEniseyskiy district, 4486 .. 7952.1 kilos/person in Turukhansliy district, and $1562.0 \quad \ldots \quad 2023.6$ kilos/person in Sharyipovskiy district.

Huge industrial enterprises operating in nonferrous metallurgy, heat and power engineering, mining and metallurgy can be called most significant emission sources creating high technogenic burden for Krasnoyarsk region population as they pollute settlement air with hazardous chemicals. Among such enterprises we can name "Krasnoyarskiy aluminium plant" RUSAL public corporation, "Krasnoyarskaya Heat Station No. 1" public corporation, "Krasnoyarskaya Heat Station No. 2" public corporation, "Krasnoyarskaya Heat Station No. 3" public corporation, "Eniseyskaya heat generating company (TGK-13)" public corporation, "Nazarovskaya State District Power Station" public corporation, "Achinsky aluminous plant" RUSAL public corporation, "GMK Norilskiy Nickel" public corporation, "Krasnoyarskaya State District Power Station No. 2" branch of "OGK-2" public corporation, "Berezovskaya State District Power Station" branch of "E.ON Rossia" public corporation, "Vankorneft" Ltd, :Polus" Ltd, "Gorevskiy ore mining and processing enterprise" public corporation, "Novoangarskiy beneficiating plant" LLC, "Razdolinskiy Periclase plant" Ltd.

Substances belonging to $3-4^{\text {th }}$ danger categories (sulfur dioxide, carbon oxide, nitrogen oxide 97.2 ... 97.9\%) prevail in emissions structure in terms of danger categories; as for aggregate state most emissions consist of gaseous and liquid pollutants $(94.6 \ldots 95.4 \%$ of all emissions); solid pollutants account for only $4.6 \ldots$ 
$5.4 \%$ of all emissions. Sulfur dioxide is predominating among liquid and gaseous emissions $(82.9 \ldots 85.4 \%)$; the second and third places belong to carbon oxide $(8.98 \ldots 10.2 \%)$ and nitrogen oxide $(3.9 \ldots 4.3 \%)$.

Implementation of measures aimed at lowering pollutants emissions from stationary sources into settlement air in Krasnoyarsk region in 2011-2014 amounted to 75.2 .. 86.4\% of planned environmental measures and a percentage of spent funds varied from $19.3 \%$ to $98.7 \%$; the effect of taken measures also led to various decrease in emissions. In 2014 specific weight of activities aimed at lowering pollutants emissions into air increased to $84.9 \%$ of all planned activities in comparison to $84 \%$ of activities accomplished in 2013. As funds spending also increased substantially in 2014 (74.0\% against $19.2 \%$ of all allocated funds in 2013) decrease in emissions after those activities amounted to 991.656 tons/a year or $69.1 \%$ of expected decrease (it was $51.0 \%$ in 2013) (Table 1).

Air quality monitoring in settlements was accomplished by Federal Hydrometeorology and Environmental Monitoring Service, Federal Service for Surveillance on Consumer Rights protection and Human Well-being, and other organizations, at 88-94 observation stations, 61-67 of them being movable and 27 immovable, placed in 8 urban districts and 2 municipal districts of Krasnoyarsk region (Table 2).

Table 1

Implementation of measures aimed at lowering pollutants emissions from stationary sources into settlements air in Krasnoyarsk region

\begin{tabular}{|c|c|c|c|}
\hline Header & Planned & $\begin{array}{c}\text { Accomplished } \\
\text { (spent) }\end{array}$ & $\%$ of planned \\
\hline \multicolumn{4}{|c|}{2011} \\
\hline Number of activities, quantity & 177 & 153 & 86.4 \\
\hline Funds, thousand rubles & 7294773.6 & 7201035 & 98.7 \\
\hline Decrease in emissions after activities, tons/year & 4826.329 & 1193.138 & 24.7 \\
\hline \multicolumn{4}{|l|}{ 年 } \\
\hline Number of activities, quantity & 202 & 152 & 75.2 \\
\hline Funds, thousand rubles & 11319556.7 & 2448304 & 21.6 \\
\hline Decrease in emissions after activities, tons/year & 1332889.65 & 2379.102 & 0.2 \\
\hline \multicolumn{4}{|l|}{ 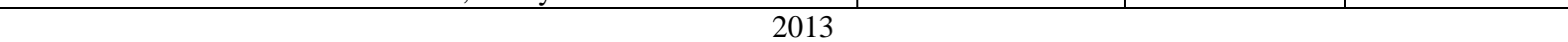 } \\
\hline Number of activities, quantity & 206 & 173 & 84.0 \\
\hline Funds, thousand rubles & 3529303.4 & 678631.4 & 19.2 \\
\hline Decrease in emissions after activities, tons/year & 4152.938 & 2116.190 & 51.0 \\
\hline \multicolumn{4}{|l|}{ 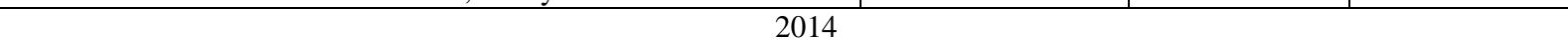 } \\
\hline Number of activities, quantity & 186 & 158 & 84.9 \\
\hline Funds, thousand rubles & 974728.3 & 721746.9 & 74.0 \\
\hline Decrease in emissions after activities, tons/year & 1435.278 & 991.656 & 69.1 \\
\hline
\end{tabular}

N o t e : data are provided by Federal Service for Statistics, Krasnoyarsk regional office.

Table 2

Number and placement of observation stations used for monitoring pollutants emissions into air in Krasnoyarsk region, Federal Information Fund 2015

\begin{tabular}{|l|c|c|c|c|c|c|}
\hline \multirow{2}{*}{ Area/city } & \multirow{2}{*}{$\begin{array}{c}\text { Number of } \\
\text { stations }\end{array}$} & \multicolumn{5}{|c|}{ Organization/type of station } \\
\cline { 3 - 7 } & & Rosgidromet & \multicolumn{2}{|c|}{ FBHO HaEC* } & Other organiations \\
\cline { 3 - 7 } & 7 & 3 & movable & immovable & movable** & immovable*** \\
\hline Achinsk & 3 & 2 & 1 & - & - & 1 \\
\hline Kansk & 54 & 8 & 16 & - & - & - \\
\hline Krasnoyarsk & 4 & 2 & 2 & - & - & - \\
\hline Lesosibirsk & 3 & 1 & 2 & - & - & - \\
\hline Minusinsk & 10 & 2 & 2 & - & 6 & - \\
\hline Nazarovo & 5 & - & & 3 & 2 & - \\
\hline Norilsk & 1 & - & 1 & - & - & - \\
\hline Sharypovo & 4 & - & - & - & 3 & 1 \\
\hline Berezovsky & & & & & & - \\
\hline
\end{tabular}




\begin{tabular}{|l|c|c|c|c|c|c|}
\hline Emelyanovsky & 3 & - & - & - & 2 & 1 \\
\hline Total & 94 & 18 & 27 & 3 & 40 & 6 \\
\hline
\end{tabular}

N o t e : * Federal Budgetary Health Organization Hygienic and Epidemiology Center.

As per Federal Information Fund data over 2011-2015 systematic laboratory monitoring of air quality was accomplished on the residential area of urban districts and district centers with total quantity of population amounting to 1684.7 ... 1807.8 thousand people. Specific weight of Krasnoyarsk region population living in the areas with air quality monitoring accounted for $61.4 \%$ in 2015.

A list of chemical pollutants in Settlements air in Krasnoyarsk region in 2011-2015 included 26 ... 33 chemicals and chemical compounds; levels exceeding maximum permissible concentration were detected for $53.3 \ldots 76.9 \%$ of all examined substances in some years. Research results for 2011-2015 show that nitrogen dioxide, benzpyrene, suspended solids, carbon oxide, formaldehyde, sulfur dioxide and other specific substances are most frequently registered in air in quantities exceeding hygienic standards [4].

Chemicals contents in settlement air in Krasnoyarsk region in 2011-2015 exceeded hygienic standards in such industrial cities as Achinsk, Kansk, Krasnoyarsk, Lesosibirsk, Minusinsk, Nazarovo, and Norilsk, and in Berezovskiy and Emelyanovskiy districts. 22 chemicals were present in air in quantities equal to 2-5 maximum permissible concentrations. Here the greatest non-conformity to standards was detected for benzpyrene, suspended solids, nitrogen and sulfur dioxides, and formaldehydes in most areas, and as for other specific substances their concentrations were unacceptable only in some separate areas.

Chemicals content in settlement air in Krasnoyarsk region exceeding 5 maximum permissible concentrations is characteristic for 13 substances; it is constantly true for benzpyrene, for suspended solids in most areas; primary pollutants (nitrogen oxide and dioxide, sulfur dioxide) and specific pollutants ( hydrochloride, dimethylbenzene, formaldehyde, ethylbenzene, copper oxide in terms of copper, nickel oxide in terms of nickel, lead and its non-organic compounds) were registered in some areas, such as Krasnoyarsk and Norilsk.

Assessment of air pollution effect on population health was based on health risk assessment methodology. Such health risk was caused by influence of chemical pollutants with both general toxic effects (non-carcinogenic risk) and carcinogenic effects (carcinogenic risk). Assessment was accomplished basing on the results of quantitative chemical air analyses taken for a 1-year-period of averaging regional information fund containing social and hygienic monitoring data received in 2015. Assessment showed that population in big industrial cities in Krasnoyarsk region ran increased risk of malignant neoplasm evolvement, respiratory organs diseases, immune system disorders, and blood and eyes diseases. (Table 3).

Carcinogenic and non-carcinogenic risks caused by air pollution in Krasnoyarsk region cities in 2015

\begin{tabular}{|l|c|l|}
\hline \multicolumn{1}{|c|}{ City } & $\begin{array}{c}\text { Total carcinogenic } \\
\text { individual risk }\end{array}$ & $\begin{array}{l}\text { Total non-carcinogenic risks in terms of vital organs and systems (maximum } \\
\text { danger index) }\end{array}$ \\
\hline Achinsk* & $2.37 \mathrm{E}-04$ & $\begin{array}{l}12.17 \text { (respiratory organs), } 7.84 \text { (immunity), 5.96 (eyes), 3.54 (blood), 3.0 } \\
\text { (mortality), 2.28 (development) }\end{array}$ \\
\hline Kansk* & $1.72 \mathrm{E}-04$ & $\begin{array}{l}6,23 \text { (immunity), 5.72 (respiratory organs), } 4.31 \text { (eyes), 2.23 (blood), 1.92 } \\
\text { (development) }\end{array}$ \\
\hline $\begin{array}{l}\text { Krasnoyarsk } \\
*\end{array}$ & $3.87 \mathrm{E}-04$ & $\begin{array}{l}15.77 \text { (respiratory organs), 7.8 (immunity), 5.43 (development), 2.72 (blood), } \\
2.59 \text { (eyes), 2.57 (CNS), 2.37 (CVS) }\end{array}$ \\
\hline Lesosibirsk* & $1.54 \mathrm{E}-04$ & $\begin{array}{l}8.24 \text { (respiratory organs), 7.18 (immunity), 3.81 (eyes), 3.7 (development), } \\
2.81 \text { (mortality) }\end{array}$ \\
\hline Minusinsk* & $1.06 \mathrm{E}-04$ & $\begin{array}{l}14.97 \text { (immunity), 13.07 (development), } 4.87 \text { (respiratory organs), 2.33 } \\
\text { (eyes), 1.46 (blood) }\end{array}$ \\
\hline
\end{tabular}


Hygienic assessment of ambient air quality and health risks to population of Krasnoyarsk region

\begin{tabular}{|l|l|l|}
\hline Nazarovo* & $6.09 \mathrm{E}-05$ & $\begin{array}{l}4.7 \text { (immunity), } 4.4 \text { (respiratory organs), } 3.44 \text { (development), 1.58 (mortality), } \\
1.45 \text { (eyes) }\end{array}$ \\
\hline Norilsk** & $9.76 \mathrm{E}-04$ & $\begin{array}{l}245.0 \text { (respiratory organs), 145.4 (systematic influence), 65.4 (blood), } 29.14 \\
\text { (mortality), 1.82 (CNS, development), 1.55 (CVS) }\end{array}$ \\
\hline
\end{tabular}

Note:* - risk is calculated according to research results obtained by FSBE "Srednesibirsloe UGMS"; ** - risk is calculated according to research results obtained by Rospotrebnadzor organizations; CVS - cardiovascular system, CNS central nervous system.

If the existing pollution levels in terms of carcinogens are not lowered in the next 70 years, risks of cancer evolvement for people living in Achinsk, Kansk, Krasnoyarsk, Lesosibirsk, Minusinsk and Norilsk, are going to be higher than acceptable risk level for settlements (1,0E-04). Formaldehyde makes for the greatest part of carcinogenic risk among monitored carcinogens in 5 industrial cities - Achinsk, Kansk, Lesosibirsk, Minusinaks, and Nazarovo. Higher carcinogenic risk related to air pollution is detected in Krasnoyarsk (due to benzene and formaldehyde out of 4 monitored carcinogens); in Norilsk (cobalt and nickel compounds and benzene out of 4 monitored carcinogens). Given the aggregate effect of chemical pollutants, people living in big industrial cities run high risks of respiratory organs diseases and immune system disorders, as well as development process disorders.

Over the last years chemical pollutants emissions into air in industrial cities of Krasnoyarsk regions have been decreasing; and as various activities aimed at improving air quality have been accomplished we can see that high carcinogenic health risks have also decreased in Kansk and Minusinsk though they are still beyond being acceptable. In Nazarovo such risks are now lower than the top level of acceptable risk.

Air assessment in settlements assessed in terms of non-carcinogenic risks values in 2015 in comparison with 2014 showed that possibility of chronic non-specific diseases decreased (danger index for vital organs and systems); risk of respiratory organs diseases became lower in Achinsk, Kansk, Nazarovo and Minusinsk; risk of eyes diseases, in Kansk, Krasnoyarsk, Minusinsk and Nazarovo; risk of immune system disorders, in Achinsk, Kansk, Krasnoyarsk, Lesosibirsk, and Norilsk; mortality rate became lower in Lesosibirsk and Nazarovo.

\section{Conclusion}

Thus, air in some settlement in Krasnoyarsk region, primarily Achinsk, Kansk, Krasnoyarsk, Lesosibirsk, Minusinsk, and Norilsk, is characterized with various pollutants concentrations exceeding hygienic standards; among such pollutants we can name benzpyrene, suspended solids, sulfur and nitrogen dioxides, formaldehyde, and some others. Economic entities in these settlements break legislation requirements in the sphere of sanitary and epidemiologic welfare of the population. Possibility of population health disorders caused by risk factors is growing. Health risks of respiratory organs diseases, immune system disorders, blood and bloodmaking organs diseases as well as additional mortality are assessed as unacceptable.

If we want to secure air quality in Krasnoyarsk region settlements we should implement a set of measures aimed at its improvement.

Detected population health risks caused by air pollution can be used as additional criterion when choosing priority objects in the process of inspections planning within the framework of risk-oriented model implementation into surveillance aimed at securing sanitary and epidemiologic welfare of the population.

\section{References}

1. Dement'ev A.A., Lyapkalo A.A., Curgan A.M. Dinamika zabolevaemosti detskogo naselenija, prozhivajushhego $\mathrm{v}$ rajonah goroda s razlichnym kachestvom atmosfernogo vozduha [Dynamics of morbidity in children who lives in the city districts with different air quality]. Fundamental'nye issledovanija, 2014, no. 7-3, pp. 473-477. (in Russian).

2. Zaitseva N.V., May I.V., Klein S.V. Optimizacija programm nabljudenija za kachestvom atmosfernogo vozduha selitebnyh territorij $\mathrm{v}$ sisteme social'no-gigienicheskogo monitoringa na baze prostranstvennogo analiza $\mathrm{i}$ ocenki riska dlja zdorov'ja naselenija [Optimization of programs for monitoring air quality in residential areas in the system of social and hygienic monitoring based on spatial analysis and risk assessment for human health]. Permskijmedicinskijzhurnal, 2010, vol. 27, no. 2, pp. 130-138. (in Russian).

3. Zaitseva N.V., May I.V., Shur P.Z. Aktual'nye problemy sostojanija sredy obitanija i zdorov'ja naselenija stran sodruzhestva nezavisimyh gosudarstv [Actual problems of inhabitancy state and health of the population in commonwealths of independent states]. Izvestija Samarskogo nauchnogo centra Rossijskoj akademii nauk, 2012, 
vol. 14, no. 5-2, pp. 527-533. (in Russian).

4. Zaryaeva E.V. Neobhodimost' upravlenija kachestvom atmosfernogo vozduha na territorijah riska Voronezhskoj oblasti [The need for quality control of atmospheric air at risk areas Voronezh]. Vestnik Voronezhskogo gosudarstvennogo tehnicheskogo universiteta, 2010, vol. 6, no. 11, pp. 185-186. (in Russian).

5. Ryzhakov S.A., Zaitseva N.V., May I.V., Alekseev V.B., Podluzhnaja M.Ja., Kiryanov D.A. Makrojekonomicheskij analiz poter' zdorov'ja, verojatnostno obuslovlennyh jemissijami zagrjaznjajushhih veshhestv $\mathrm{v}$ atmosfernyj vozduh [Macroeconomic analysis of health loss probability associated with emissions of polluting substances in the air]. Permskijmedicinskijzhurnal, 2009, vol. 26, no. 3, pp. 139-143. (in Russian).

6. Mishina A.L. Ispol'zovanie metodologii ocenki riska dlja upravlenija kachestvom atmosfernogo vozduha [The use of risk assessment methodology for air quality management]. Zdorov'e naselenija i sreda obitanija, 2009, no. 6, pp. 26-29. (in Russian).

7. Rukovodstvo po ocenke riska dlja zdorov'ja naselenija pri vozdejstvii himicheskih veshhestv, zagrjaznjajushhih okruzhajushhuju sredu R 2.1.10.1920-04 [Guide to health risk assessment when exposed to chemicals polluting the environment R 2.1.10.1920-04 P]. Moscow: Federal'nyj centr Gossanjepidnadzora Minzdrava Rossii, 2004, 143 p. (in Russian).

8. Popova A.Ju., Bragina I.V., Simkalova L.M., Mitrohin O.V., Hmura M.V., Zaitseva N.V., May I.V., Shur P.Z., Kiryanov D.A., Chigvintsev V.M., Kamaltdinov M.R., Sedusova Je.V., Parfenov A.V., Romanenko K.V., Kuzmin S.V., Dikonskaja O.V., Gurvich V.B., Sboev A.S., Horoshavin V.A., Akimova L.N. [et al]. Riskorientirovannaja model' kontrol'no-nadzornoj dejatel'nosti v sfere obespechenija sanitarno-jepidemiologicheskogo blagopoluchija. Klassifikacija vidov dejatel'nosti i hozjajstvujushhih subektov po potencial'nomu risk prichinenija vreda zdorov'ju cheloveka dlja organizacii planovyh kontrol'no-nadzornyh meroprijatij: Metodicheskie rekomendacii. MR 5.1.1. - 14 [The risk-oriented model of control and supervisory activities in the field of sanitary and epidemiological welfare. Classification of activities and businesses on the potential risk of harm to human health for the organization of the planned supervisory activities: Guidelines. MP 5.1.1. -14]. Moscow, 2014,71 p. (in Russian).

9. Tuljakova O.V., Sizova E.N. Zabolevaemost' detej v zavisimosti ot vozrasta i nalichija ajerotehnogennogo zagrjaznenija [The incidence of children in dependence of age and the presence of man-caused contaminants in air]. Novyeissledovanija, 2012, no. 2 (31), pp. 47-55. (in Russian).

10.James P., Ito K., Banay R.F., Buonocore J.J., Wood B., Arcaya M.C. A health impact assessment of a proposed bill to decrease speed limits on local roads in Massachusetts. International Journal of Environmental Research and Public Health, 2014, vol. 11 (10), pp. 10269-10291.

11.Heller J., Givens M.L., Yuen T.K., Gould S., Jandu M.B., Bourcier E., Choi T. Advancing efforts to achieve health equity: equity metrics for health impact assessment practice. International Journal of Environmental Research and Public Health, 2014, vol. 11 (11), pp. 11054-11064.

12.Chart-Asa C., Gibson J.M. Health impact assessment of traffic-related air pollution at the urban project scale: Influence of variability and uncertainty. Science of the Total Environment, 2015, pp. 506-507: 409-42. DOI: 10.1016/j.scitotenv.2014.11.020.

13.Kampa M., Castanas E. Human health effects of air pollution. Environmental Pollution, 2008, no. 151, pp. $362-367$

14.Kumar N., Foster A.D. Air quality interventions and spatial dynamics of air pollution in delhi and its surroundings. International Journal of Environment and Waste Management, 2009, vol. 4, no. 1-2, pp. 85-111.

15.Suther E, Sandel M. Health impact assessments. Rhode Island Medical Journal, 2013, vol. 96 (7), pp. $27-$ 30.

16. Haigh F., Baum F., Dannenberg A.L., Harris M.F., Harris-Roxas B., Keleher H., Kemp L., Morgan R., $\mathrm{Ng}$ Chok H., Spickett J., Harris E. The effectiveness of health impact assessment in influencing decision-making in Australia and New Zealand 2005-2009. MC Public Health, 2013. DOI: 10.1186/1471-2458-13-1188.

Goryaev D.V., Tikhonova I.V. Hygienic assessment of ambient air quality and health risks to population of Krasnoyarsk region. Health Risk Analysis, 2016, no. 2, pp. 76-83. 